Miejmy nadzieję, że książka poświęcona pierwszemu polskiemu uczonemu, który habilitował się $\mathrm{z}$ historii wychowania, stanie się dobrym początkiem dla publikacji poświęconych wybitnym badaczom dziejów edukacji w Polsce.

Mikolaj Brenk

\title{
Z dziejów ruchu harcerskiego. Studia - Szkice - Materialy 1911-2006, pod red. E. Czop, Oficyna Wydawnicza „Mercator”, Rzeszów 2006
}

Przedłożona do recenzji książka stanowi pokłosie sympozjum naukowego, które odbyło się w Rzeszowie w dniach 9-11 września 2006 r.. Sympozjum zorganizował Instytut Historii Uniwersytetu Rzeszowskiego w kooperacji z Podkarpacką Komendą ZHP. Impuls do jego zwołania dała zbliżająca się setna rocznica narodzin skautingu i dziewięćdziesiąta piąta rocznica powstania pierwszych drużyn skautowych w Polsce.

Tematem przewodnim prezentowanej publikacji są dzieje ruchu harcerskiego na ziemiach polskich w latach 1911-2006. Szerokie ujęcie zagadnienia i podana cezura czasowa sugerują wielopłaszczyznowość podjętych rozważań i ich interdyscyplinarność. Autorami zamieszczonych w zbiorze tekstów są zarówno pedagodzy, lekarze, jak i historycy. Fakt ten pozwala na uchwycenie badanego problemu w różnych perspektywach i tym samym ubogaca wiedzę odbiorcy. Po wtóre, jak na publikację posympozjalną jest ona dość nietypowa, bo łączy w sobie refleksję naukową i tę, którą pisze praktyka życia harcerskiego. Obok rozważań czysto naukowych są bowiem i te, które napisali działacze harcerscy, którzy na co dzień zajmują się szerzeniem tradycji harcerskiej.

Wspomniana interdyscyplinarność, szeroka cezura czasowa, jak i połączenie narracji naukowej z popularyzatorską spowodowało, że opracowanie zgłoszonych tekstów mogło stanowić dla organizatorów duże wyzwanie. Końcowy efekt ich pracy przekonuje, że z powierzonego im zadania wyszli obronną ręką, gdyż całość charakteryzuje się dużym stopniem spójności wewnętrznej.

Publikacja zyskała układ tematyczno-chronologiczny i składa się z ośmiu podstawowych części, w których skład wchodzi od jednego do siedmiu opracowań. Poza sformalizowanym podziałem znajduje się gawęda profesora Zbigniewa Mańkowskiego, która stanowi doskonały wstęp do zasadniczych rozważań. Gawęda ma charakter wspomnieniowy i przywołuje działalność profesora $w$ harcerstwie okręgu łańcuckiego w drugiej połowie lat 40. XX w. Był to czas dramatyczny w historii Polski, a ingerencja świata polityki w świat organizacji młodzieżowych - w tym harcerstwa - szczególnie agresywna. Świadczą o tym właśnie powyższe wspomnienia, w których profesor nieraz nadmienia o wysiłkach decydentów w kierunku upolitycznienia działalności drużyn harcerskich. Efektywność tych oddziaływań była jednak różna, a zjawiskiem bardzo charakterystycznym było to, że jakby na przekór inwigilacji, zastraszaniu i konkretnym aktom terroru wobec harcerzy, organizacja starała się prowadzić w miarę normalną (biorąc pod uwagę ówczesną sytuację społeczno-polityczną) działalność statutową.

Wątek oddziaływania czynników politycznych na funkcjonowanie ZHP przewija się zresztą niemalże we wszystkich zamieszczonych $w$ omawianym zbiorze publikacjach. 
Najbardziej dobitnie jest on ukazany jednak w części szóstej, w całości poświęconej czasom Polski Ludowej. Do zagadnienia wrócę przy okazji omawiania wzmiankowanego rozdziału recenzowanej pracy.

Jak już wspomniałam, całość zyskała podział o charakterze tematyczno-chronologicznym i tym samym pierwsza część książki ma rys najbardziej ogólny. Omawia bowiem zagadnienia podstaw ideologicznych i organizacyjnych harcerstwa na ziemiach polskich. Na szczególną uwagę zasługuje tu opracowanie Jerzego Chrabąszcza, który przedmiotem swoich rozważań uczynił etos harcerski. Szukając rdzenia owego etosu, wyróżnił Autor kilka grup źródel, które ukonstytuowały zbiór wartości i idei charakteryzujących formację harcerską. Do źródeł tych należą przede wszystkim geneza ruchu, deklaracje statutowe, harcerska metodyka wychowania, tradycja i historia, symbolika atrybutów harcerstwa, formy pracy oraz obrzędowość. Już pobieżny wgląd w wymienione grupy źródeł każe domniemywać, że poruszony temat jest bardzo obszerny i śmiało mógłby stanowić przyczynek do oddzielnej publikacji. Potraktowanie go jako jednego z rozdziałów wymaga dużych umiejętności syntetyzowania i takiej prezentacji treści, aby uniknąć uogólnień i uproszczeń. Lektura tekstu J. Chrabąszcza przekonuje jednak, że autor takie kompetencje posiada i potrafił przedstawić wspomniane zagadnienia w sposób zwięzły, a zarazem wyczerpujący.

Kolejne opracowania części pierwszej stanowią niejako logiczną kontynuację rozważań J. Chrabąszcza, gdyż poświęcone zostały harcerskiemu kodeksowi honorowemu (K. Wais), roli obozownictwa w programie wychowawczym harcerstwa (A. Gardzińska) i problematyce zarządzania informacją w ZHP (K. Wais).

Pierwsza $\mathrm{z}$ wymienionych publikacji autorstwa Kamila Waisa koncentruje się na skonfrontowaniu Harcerskiego Kodeksu Honorowego ze znanym Polskim Kodeksem Honorowym Władysława Boziewicza. Autor dokonując porównania obu kodeksów, wyraźnie zaznacza, że Kodeks Boziewicza służył co najwyżej jako inspiracja do powstałego w 1925 r. Harcerskiego Kodeksu Honorowego. Ze względu na - ujmijmy to delikatnie radykalność rozwiązań ewentualnych kwestii spornych u Boziewicza - nie było mowy, aby HKH stał się jego prostym odzwierciedleniem. W HKH sposoby rozwiazywania konfliktów uległy „wysublimowaniu”, a pojedynek został zastąpiony przez rozwiązanie pokojowe w postaci negocjacji. Podstawą postawy społecznej harcerza miał być honor, który można uznać za cechę konstytuującą wszelkie jego działania. Tak pojęte zasady jak słusznie zauważa $\mathrm{K}$. Wais - służyły nie tylko doraźnemu rozwiązywaniu konfliktów wewnątrzgrupowych, ale i utrwaleniu etosu harcerskiego.

Istotną rolę $\mathrm{w}$ procesie uwewnętrznienia wartości płynących $\mathrm{z}$ etosu harcerskiego odgrywały też obozy skautowe, które stanowią przedmiot opracowania Adrianny Gardzińskiej. Autorka skoncentrowała swą uwagę na tych, które organizowane były w latach 1910-1939 i które czerpały z tradycji skautingu - głównie za sprawą jego twórcy Baden-Powella. Jak można się domyśleć, celem organizowania obozów był nie tylko relaks i wypoczynek - traktowano je też jako konkretną metodę wychowawczą. Uczestnictwo w obozie skautowym miało w swym zamierzeniu wpajać ich uczestnikom podstawowe wartości płynące $\mathrm{z}$ bycia członkiem grupy: odpowiedzialność, lojalność, odporność na trudy, pomysłowość i solidarność. Na ten aspekt obozownictwa autorka zwraca największą uwagę i dlatego tym bardziej żałować należy, że w swym opracowaniu skupiła 
się bardziej na przedstawieniu faktograficznej warstwy podjętego problemu. Dobrym uzupełnieniem narracji byłoby ukazanie konkretnych działan wychowawczych podejmowanych na obozach skautowych i sposobów, za pomocą których starano się zaszczepić w skautach wspomniane poprzednio wartości.

Ostatnim opracowaniem w tej części jest publikacja K. Waisa, który w bardzo szczegółowy sposób omawia kwestię zarządzania informacją w ZHP do 1939 r. Sprawnej komunikacji miały służyć nie tylko odprawy, dokumentacja w postaci listów i rozkazów, ale i sprawozdawczość. Ta ostatnia zresztą miała swoją negatywną konsekwencję w postaci biurokracji, którą w drodze odpowiednich uregulowań starano się sukcesywnie zmniejszać.

Autorzy tekstów zamieszczonych w drugim rozdziale pracy (J. Wojtycza, P. Matys, S. Krakowski, A. Krzanowski) koncentrują z kolei uwagę odbiorcy na genezie i początkach ruchu skautowego na ziemiach polskich. Mimo, że opracowania mają silnie regionalny charakter, to jednak historia poszczególnych drużyn skautowych została ukazana na tle ogólnych zmian społeczno-politycznych oraz funkcjonowania ruchu skautowego w ogóle. Bardzo wartościowym uzupełnieniem tekstów obrazujących historię i działalność poszczególnych drużyn skautowych z różnych regionów Polski, jest opracowanie Adama Krzanowskiego. Etos harcerski formowały nie tylko obrzędowość, formy pracy, czy odpowiednie uregulowania, ale i elementy dziedzictwa historycznego. Na ten ostatni aspekt zwrócił właśnie uwagę A. Krzanowski, prezentując postaci patronów poszczególnych drużyn skautowych w latach 1911-1939. Patroni drużyn to głównie bohaterowie historii Polski, którzy przykładem swego życia, poświęceniem i pracą dla Ojczyzny kształtowali sferę aksjologiczną osobowości skautów.

Trzecia część recenzowanej publikacji poświęcona została w całości okresowi I wojny światowej i związanymi z nią losami polskiego skautingu. We wszystkich opracowaniach (L. Dalla, J. Leskiewicz i I. Kozimali, J. Szczepańskiego) punkt ciężkości położony został na ukazanie bohaterstwa skautów, którzy mimo młodego wieku z oddaniem walczyli o niepodległość Polski. Bohaterstwo drużyn skautowych, a jednocześnie ich tragizm widać szczególnie $\mathrm{w}$ opracowaniu Janusza Szczepańskiego ukazującego wydarzenia związane z wojną polsko-sowiecką $1920 \mathrm{r}$.

Za sprawą rozdziału czwartego przenosimy się w okres międzywojenny. Rozdział ten zawiera dwie publikacje (I. Kozimali i M. Stalki), z których jedna (I. Kozimali) omawia proces odradzania się skautingu na terenie Galicji, a druga (M. Stalki) koncentruje się na powstaniu i rozwoju harcerstwa na ziemi radomszczańskiej. Na szczególną uwagę zasługuje opracowanie Ireny Kozimali, która kwestię odradzania się skautingu na terenie Galicji wpisała w panoramę ówczesnej sytuacji społeczno-politycznej Polski. Problem integracji ziem polskich po okresie zaborów obfitował w szereg trudności natury socjologicznej, ekonomicznej i politycznej. Tym samym, jasne staje się to, że i proces integrowania się organizacji harcerskich nie należał do łatwych. Droga ku zjednoczeniu (zwłaszcza harcerstwa galicyjskiego $\mathrm{z}$ harcerstwem $\mathrm{z}$ pozostałych ziem polskich) przebiegała w atmosferze sporów, burzliwych rozmów i negocjacji. Dowodem na to są protokoły z posiedzeń Naczelnej Rady Harcerskiej, które Autorka dołączyła w formie aneksów do omawianej publikacji.

Następna część pracy - poświęcona tematyce sportu - pozostawia nas w okresie międzywojennym, ale tylko za sprawą pierwszej z zamieszczonych tam publikacji autorstwa 
Stanisława Zaborniaka. Ma ona najbardziej ogólny charakter i traktuje o działalności harcerskich klubów sportowych Drugiej Rzeczypospolitej. Autor podsumowując osiągnięcia sportowe poszczególnych organizacji sportowych zaznacza, że ich znaczenie wykraczało daleko poza rozwijanie tężyzny fizycznej i poprawianie kolejnych rekordów. $Z$ racji swego harcerskiego rodowodu, działalność wspomnianych drużyn miała silny wydźwięk społeczny polegający na popularyzacji kultury fizycznej. Nie można też zapominać o tym, że w przypadku harcerstwa, uprawianie sportu - podobnie jak pozostałe sfery aktywności posiadało wyraźny aspekt wychowawczy. Kształtowanie w harcerzach odporności na trudy, wytrwałości i sumienności odbywało się nie tylko na niwie lekkoatletyki, czy gier zespołowych, ale też i żeglarstwa. Wodniactwo zapisało się trwałą kartą w historii sportu harcerskiego, a dowodem na to są kolejne dwie publikacje (W. Podleśnego i P. Świdra oraz M. Żukrowskiego) omawiające rozwój tej dyscypliny od okresu Drugiej Rzeczypospolitej do czasów powojennych.

Rozdział szósty zatytułowany „Po kataklizmie wojny - w Polsce Ludowej” jest rozdziałem szczególnym. I to nie tylko ze względu na największą liczbę publikacji tam zawartych, ale na treść. Okres powojenny - jak wspomniałam na samym początku - był okresem szczególnie dramatycznym w historii Polski. Oznaczał czas wzmożonej indoktrynacji, prześladowań a przede wszystkim niszczenia tradycji - zwłaszcza tej z okresu międzywojennego. Świat polityki wdarł się siłą w każdy wymiar życia społecznego, a zwłaszcza w te jego aspekty, gdzie rozgrywała się „walka" o nowe pokolenie. Władza nie mogła zostać obojętna wobec kwestii wychowania i zaryzykować zostawienia instytucji wychowawczych bez nadzoru. Zainteresowanie się działalnością wszystkich organizacji młodzieżowych, w tym i harcerstwa pozostawało więc tylko kwestią czasu. Przystosowanie harcerstwa do wymogów nowej sytuacji społeczno-politycznej było równoznaczne $\mathrm{z}$ ingerencją nie tylko $\mathrm{w}$ formy aktywności, metody działania czy skład społeczny harcerstwa. Konkretne działania polityczne dotknęły też samego rdzenia organizacji, czyli jego etosu. Okazało się jednak, że pomimo tak zintensyfikowanej akcji propagandowej, harcerstwo nadal stanowiło dla władzy ludowej zagrożenie. Sięgnięto zatem do rozwiązania radykalnego i w roku 1949 ZHP zlikwidowano wcielając go w struktury ZMP. Po 1956 r., reaktywowano wprawdzie organizację harcerską i pozwolono nawet na działalność wedle własnych zasad, ale oczywistym jest fakt, że do czasu zmiany społecznej w 1989 r., była to organizacja, której niezależność pozostawiała dużo do życzenia.

Tragizm losów powojennego harcerstwa widać w każdym $\mathrm{z}$ opracowań zamieszczonych $\mathrm{w}$ omawianym rozdziale. Każdy $\mathrm{z}$ nich ma wprawdzie zaznaczony $\mathrm{w}$ tytule aspekt regionalny, ale unifikacja ówczesnego świata społeczno-politycznego powoduje, że niezależnie od regionu można zauważyć duże podobieństwo w przedstawianiu dziejów poszczególnych drużyn harcerskich. Czy będzie to więc Śląsk (K. Witkowski), ziemia rzeszowska (M. Jarosińska ), szczecińska (E. Głowacka-Sobiech), lubuska (P. Bartkowiak), czy też ogólnie Pomorze Zachodnie (T. Jasiunas, W. Kulesza), to wszędzie koleje losów organizacji były niemalże takie same. W prezentowanych materiałach wyraźnie też widać to, o czym wspominał już w swej gawędzie prof. Z. Mańkowski, a co było charakterystyczne dla życia w warunkach ładu monocentrycznego. Pomimo niekorzystnych warunków politycznych harcerze przez cały wzmiankowany okres próbowali zachować w swej działalności to, co stanowi filar organizacji harcerskiej, czyli służbę bliźniemu. 
Aktywnie więc uczestniczyli we wszelkich akcjach charytatywnych, czy innych formach pomocy. W miarę możliwości, próbowali też ocalić tradycję polskiego harcerstwa, chociaż niejednokrotnie płacili za to bardzo wysoką cenę w postaci represji politycznych.

Uzupełnieniem wspomnianych wyżej opracowań są teksty W. Golesa i M. Kowalika prezentujące sylwetki druha Stanisława Nowakowskiego i harcmistrza Stanisława Sokołowskiego.

Wspomniano nieraz, że służba na rzecz innych stanowiła jeden z filarów konstytuujących działalność ZHP. Potwierdzeniem może tu być zawartość rozdziału siódmego, w którym autorzy omawiają aktywność harcerską na polu propagowania postaw prozdrowotnych i konkretne formy pomocy dla osób chorych. W zakres wchodziło tu nie tylko organizowanie obozów leczniczo-rehabilitacyjnych dla dzieci, wsparcie wychowanków domów dziecka, ale i wyciągnięcie ręki do ludzi starszych, którzy z racji swej nieporadności potrzebowali pomocy szczególnej. Drugie z opracowań w tej części pracy (S. Hubickiej) obok działalności na rzecz osób niepełnosprawnych, omawia też działalność resocjalizacyjną, której adresatami była młodzież społecznie niedostosowana. Ukazanie tej młodzieży świata alternatywnego, $\mathrm{z}$ całym bogactwem ideałów harcerskich ma potencjalnie dużą moc wychowawczą i stanowi jeden $\mathrm{z}$ najbardziej intrygujących aspektów działalności ZHP.

Całość pracy zamyka rozdział ósmy, w którym zaprezentowano tylko jedną publikację (E. Czop), podejmującą problematykę obecności tematyki harcerskiej w działalności naukowej Wyższej Szkoły Pedagogicznej w Rzeszowie. W wyniku badań własnych Autorka ustaliła, że problematyka harcerska nie cieszy się zbytnią popularnością i mimo wielości prac, większość $\mathrm{z}$ nich ma charakter przyczynkarski bądź też popularyzatorski.

Konkluzja Edyty Czop stanowi zarazem przesłankę do sformułowania moich wniosków, które kończą niniejszą recenzję. Po pierwsze, recenzowana publikacja stanowi pozycję bardzo wartościową. Poszerza w znacznym stopniu wiedzę na temat harcerstwa i może służyć nie tylko ludziom zawodowo interesującym się tą tematyką, ale i tym, którym nie są obojętne zagadnienia związane $\mathrm{z}$ historią naszego kraju. Po drugie, bogactwo zaprezentowanego w niniejszym zbiorze materiału świadczy o tym, że dzieje harcerstwa polskiego mogą stanowić dla historyków otwartą perspektywę badawczą. Każde z prezentowanych tu zagadnień zachęca do dalszych peregrynacji naukowych i szukania odpowiedzi na pytanie o miejsce $i$ znaczenie polskiego harcerstwa $w$ dziejach narodu polskiego. 